\title{
Synthesis and Application of Nanoporous Activated Carbon in Supercapacitors
}

\author{
Aleksandrs Volperts ${ }^{1}$, Galina Dobele ${ }^{2}$, Jurijs Ozolins ${ }^{3}$, Nina Mironova-Ulmane ${ }^{4}$, \\ ${ }^{1-2}$ Latvian State Institute of Wood Chemistry, ${ }^{3}$ Riga Technical University, \\ ${ }^{4}$ Latvian University Institute of Solid State Physics
}

\begin{abstract}
Influence of the thermocatalytical synthesis on the formation of the porous structure and the properties of microporous carbon wood-based materials was shown. It was found that increase of activation temperature and addition ratio of alkali activator can be used to control not only total pore volume, but also micropore and mesopore proportion. The results of tests on the synthesized carbon materials as electrodes in supercapacitors are shown, as well as the influence of properties of the porous structure of carbon materials on working characteristics of electrodes. It was shown that the increase of activation temperature from $600^{\circ} \mathrm{C}$ to $800^{\circ} \mathrm{C}$ led to an increased proportion of mesopores in the porous structure; this negatively influencen the cell capacity of the supercapacitor. It was found that the most feasible way of production of activated cabons for the use as electrodes in supercapacitors with sulphuric acid-based electrolyte is low-temperature activation.
\end{abstract}

Keywords - Activated carbon, thermochemical activation, nanoporous materials, supercapacitors.

\section{INTRODUCTION}

The traditional way of biomass conversion is the production of wood chars and carbon materials with developed porous structure, activated carbons (AC). These materials are used as sorbents in many areas. Nowadays, the elucidation of $\mathrm{AC}$ structure is of scientific and practical interest because the areas of application of these materials are constantly widening: membrane technologies for separation of rare earth metals, metallurgy, electronics, electrochemistry, aerospace technologies, and nuclear energy. This broad spectrum of AC applications is justified by diversity of their structures that leads to different physical and chemical properties. The diversity can be achieved by certain physical-chemical treatments of the carbonaceous precursors. One of the distinctive features of plant biomass based AC is the fact that they can be obtained in various conditions of pyrolysis and activation from extremely wide range of precursors: wood chips, cellulose and lignin, lignocellulosics, nut shells, straw, peat, husks, etc. The resulting properties of $\mathrm{AC}$ will be different depending on the precursor and synthesis conditions.

Wood based carbonizates have low porosity and their structure consists of elementary crystallites divided by multiple slit-like pores [1]. These pores are filled with pyrolysis products - pyrolytic tar. In the process of activation the closed pores open up and a porous structure forms. By varying carbon materials and activation conditions (temperature, time, atmosphere) it is possible to control total porosity, pore size distribution and nature of inner space.
Chemical activation is a widely used method to produce AC with developed porosity. The most important advantage of chemical activation is the possibility to synthesize carbonaceous materials with very high specific surface, close to the theoretical limits for carbon materials.

Alkali metal hydroxides are some of the most effective activating agents allowing (in certain cases) to synthesize microporous carbon sorbents with specific surface larger than $3000 \mathrm{~m}^{2} \cdot \mathrm{g}^{-1}$ [2].

There are numerous examples of applications of AC as electrodes to perfect the storage and the transmission of electrical energy. The main areas of the research are aimed at development of carbon matrix with high specific surface and low electric resistance and with low costs of production. AC, synthesized using of alkali metal hydroxides, correspond to the above mentioned demands [3], [4].

Sorption methods and Raman spectroscopy are the most popular non-destructive techniques used to characterize carbon-containing materials [5], [6].

The Raman spectra of highly ordered graphite exhibits only one band in the region between $1100 \mathrm{~cm}^{-1}$ and $1700 \mathrm{~cm}^{-1}$ and shows second order features in the region between $2400 \mathrm{~cm}^{-1}$ and $3300 \mathrm{~cm}^{-1}$. The $\mathrm{G}$ mode of graphite near $1580 \mathrm{~cm}^{-1}$ has $\mathrm{E}_{2 \mathrm{~g}}$ symmetry and is related to the relative motion of $\mathrm{sp}^{2}$ bonded carbon atoms. The Raman spectra change significantly for disordered, finite-sized microcrystalline carbons and besides the $G$ band show the so-called $D$ band near $1350 \mathrm{~cm}^{-1}$. The origin of $\mathrm{D}$ band had long been in debate and was recently attributed to the double resonant Raman scattering. Both the $\mathrm{G}$ and $\mathrm{D}$ bands are generally attributed to graphitic $\mathrm{sp}^{2}$ bonded carbon [7]. The intensity ratio of $G$ and $D$ bands as well as their wavenumbers and widths are useful quantitative criteria to compare the degree of structural order of different carbon forms.

In the development of new systems for the modern electricpower industry one important problem is the research devoted to application of electric double layer capacitors or supercapacitors (SC) - there porous AC are used as the main material of electrodes. The development and the research of $\mathrm{SC}$ is an important subject worldwide. It is known that energy capacity of carbon electrode is influenced by the following AC parameters: the raw material used, its dispersity and elemental composition, modes of carbonization and activation, the characteristics of porous structure, etc. [8].

This work is devoted to the study of influence of characteristics of porous structure of a wood based carbon 


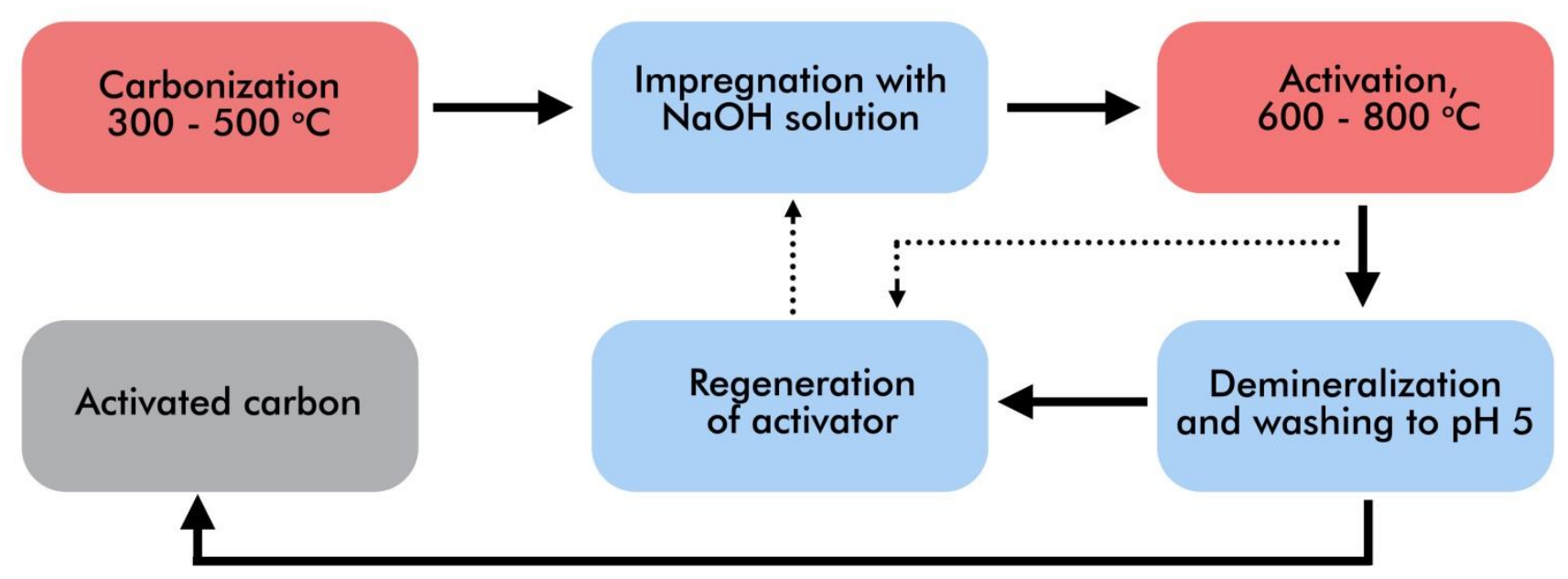

Fig. 1. Schematic representation of carbonization and activation of wood precursors.

material for its application use in electric double layer capacitors (supercapacitors) with sulfuric acid as electrolyte.

\section{MATERIALS AND METHODS}

\section{A. Raw material, carbonization and activation}

Birch wood chips $(0.2 \mathrm{~mm}-0.4 \mathrm{~mm})$ were used as the raw material.

AC synthesis is schematically illustrated in Fig. 1. It consists of two stages of thermal treatment - at the first stage raw material was carbonized in nitrogen atmosphere at $400{ }^{\circ} \mathrm{C}$ for $150 \mathrm{~min}$.

At the second stage carbonizate was impregnated with $\mathrm{NaOH}$ water solution (weight fraction $50 \%$ ). The ratio of carbonizate and activator was varied from 1:2 to $1: 4$. The mixture was activated at temperatures in range between $600{ }^{\circ} \mathrm{C}$ and $800{ }^{\circ} \mathrm{C}$ for 120 min in Nabertherm $L-40$ muffle furnace in an argon flow $\left(300 \mathrm{l} \cdot \mathrm{h}^{-1}\right)$. The pyrolysis product was

washed with deionized water, demineralized with hydrochloric acid and washed with deionized water until filtrate $\mathrm{pH}$ was 5 . The obtained $\mathrm{AC}$ was dried overnight at $105^{\circ} \mathrm{C}$. Ash content in the $\mathrm{AC}$ was found to be $0.1 \%-0.4 \%$. The main variables in the experiment were the activation temperature and the carbonizate and activator ratio.

\section{B. Assesment of Porous Structure}

Porous structure was assessed by $\mathrm{N}_{2}$ adsorption at $77 \mathrm{~K}$ (Kelvin 1042, Costech Instruments). Pore volume was calculated using Dubinin-Radushkevich and BrunauerEmmet-Teller (BET) theories and $\mathrm{N}_{2}$ sorption isotherms [9].

\section{Raman Scattering}

Raman spectra of carbon materials were measured in backscattering geometry at room temperature through microscope objective (magnification $50 \times$ ) using a micro-Raman spectrometer equipped with argon laser $(514.5 \mathrm{~nm}$, maximum continous-wave power $10 \mathrm{~mW}$ ). The spectral signal was dispersed by grating ( 2400 grooves per $1 \mathrm{~mm}$ ) onto Peltier- cooled $\left(-60^{\circ} \mathrm{C}\right) \mathrm{CCD}$ detector. Frequency shifts in the Raman spectra were calibrated using $\mathrm{CaWO}_{4}$ as a reference.

\section{Supercapacitor Assembly}

AC was first mixed with ethanol, then with a binder - a water suspension of PTFE $F-4 D$ (10\% from mass of dry electrode) was added. The resulting mixture was calendered in rollers. The electrodes were dried and then impregnated with $4.9 \mathrm{M} \mathrm{H}_{2} \mathrm{SO}_{4}$ solution in water. Cellulosic separator NKK TF $4030(10 \mu \mathrm{m})$ was used to make a supercapacitors (SC). The electrode area was $4.15 \mathrm{~cm}^{2}$. Foil from thermally expanded graphite $(200 \mu \mathrm{m})$ was used as a current collector. The assembled SC were pressed under 10 atm pressure in a dry box. SC capacity was assessed using potentiostat ELLINS 30-S at $1 \mathrm{~V}$ for $5 \mathrm{~min}$. Inner resistance was calculated by voltage drop at current transient in the beginning of SC discharge. Capacities shown were calculated using the dry mass of an electrode without the electrolyte.

\section{RESULTS AND DISCUSSION}

\section{A. Raman Spectroscopy}

Raman spectroscopy was used to compare structures of charcoal and activated carbon (AC) synthesized at $700{ }^{\circ} \mathrm{C}$ and carbonizate to activator ratio was 2 . The Raman-active vibration numbering for natural single-crystal graphite exhibits a single Raman peak at around $1580 \mathrm{~cm}^{-1}$, called the $\mathrm{G}$ peak. This peak is associated with the in-plane $\mathrm{C}-\mathrm{C}$ stretching mode of $\mathrm{sp}^{2}$ hybridized carbon atoms. If the longrange order of the crystalline material is lost and the carbon phase becomes glassy, $G$ and the D peaks both broaden [7]. Three Raman scattering peaks near $1364 \mathrm{~cm}^{-1}, 1596 \mathrm{~cm}^{-1}$ and $2325 \mathrm{~cm}^{-1}$ are observed. The peak at $1580 \mathrm{~cm}^{-1}$ ( $\mathrm{G}$ band) is attributed to an $E_{2 g}$ mode of graphite and is related to the vibration of $\mathrm{sp}^{2}$ bonded carbon atoms. For polycrystalline graphite, depending on the size of the crystallites, a second peak at $1350 \mathrm{~cm}^{-1}$ appears, namely the disorder or D peak [10]. Note that in a perfect graphite crystal the first-order vibrational mode of the $\mathrm{D}$ band is forbidden because of 


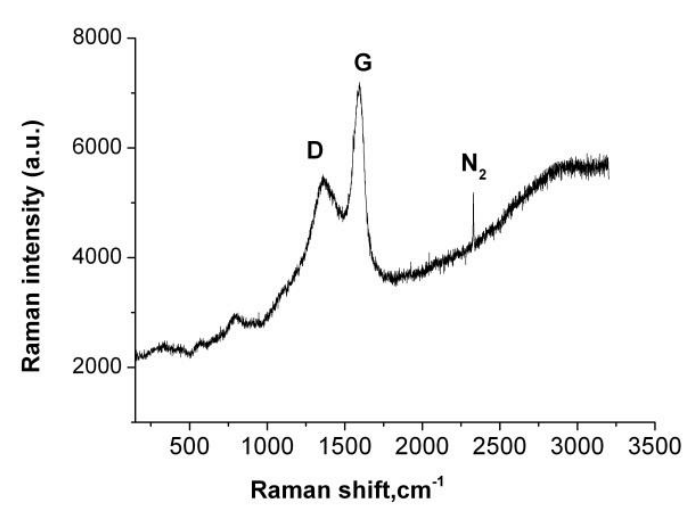

Fig. 2. Micro-Raman scattering spectrum of wood charcoal.

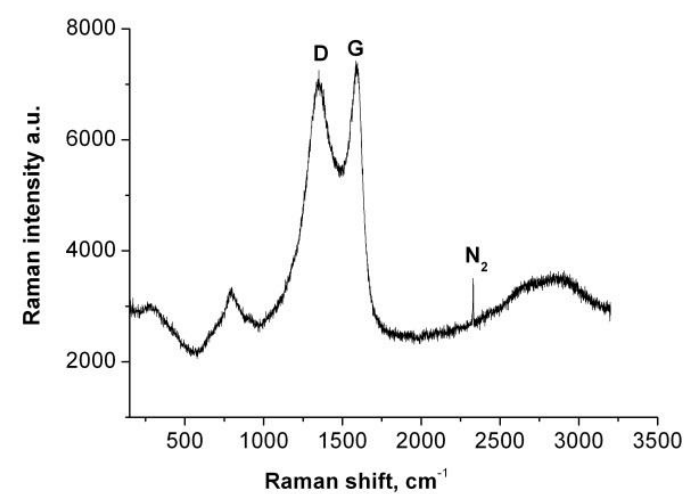

Fig. 3. Micro-Raman scattering spectrum of activated carbon (activation temperature $700^{\circ} \mathrm{C}$, activator to carbonizate ratio $1: 2$ ).

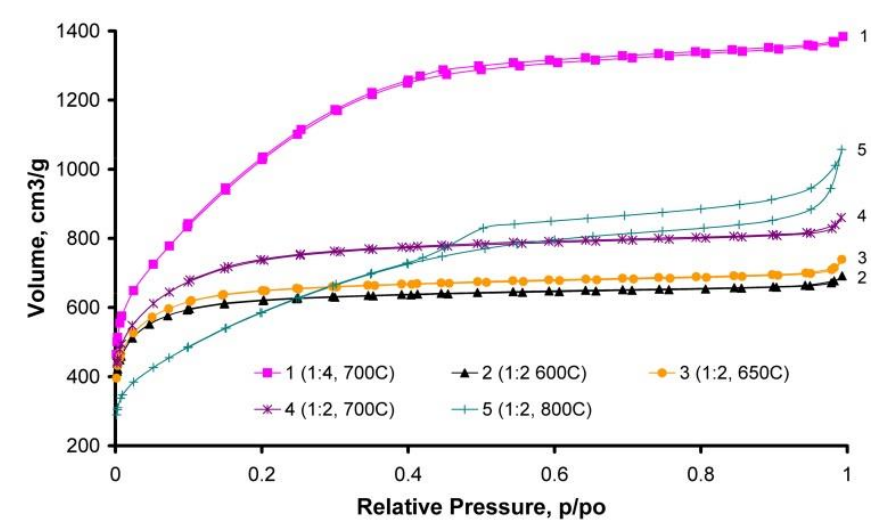

Fig. 4. AC nitrogen adsorption isotherms at $77 \mathrm{~K}$ for materials made with differing carbonizate to activator ratios and activation temperatures.

selection rules. Decreasing the particle size or bending the lattice fringes may activate this band [11]. We could see this phenomenon: after activation of carbon the intensity of Raman scattering $\mathrm{D}$ band increased, if particle size of carbon decreased (Fig. 2 and Fig. 3). Stretch vibrations of $\mathrm{N}_{2}$ in the ambient atmosphere might cause the sharp (narrow) peak near $2325 \mathrm{~cm}^{-1}$ [10].

\section{B. Porous Structure Assessment}

$\mathrm{AC}$ pore structure characteristic for use as electrodes in supercapacitors was investigated using nitrogen sorption isotherms (Fig. 4).

The studied samples were first carbonized at $400{ }^{\circ} \mathrm{C}$ and then activated at carbonizate to $\mathrm{NaOH}$ ratio 1:2 (Fig. 4, isotherms $2-5$ ) and 1:4 (Fig. 4, isotherm 1) in isothermal conditions at $600{ }^{\circ} \mathrm{C}, \quad 650{ }^{\circ} \mathrm{C}, \quad 700^{\circ} \mathrm{C}$ and $800{ }^{\circ} \mathrm{C}$ temperatures. Judging by the shape of isotherms, samples obtained at $600{ }^{\circ} \mathrm{C}, 650^{\circ} \mathrm{C}$ or $700{ }^{\circ} \mathrm{C}$ temperatures (Fig. 4, isotherms 2-4) were microporous. With increase of activation temperature, the volume of adsorbed nitrogen increased as well. At activation temperature $800^{\circ} \mathrm{C}$ (Fig. 4, isotherm 5) the shape of isotherm changed. The appearance of hysteresis is an indication of capillary condensation of the sorbate, which also indicates the increase of number of mesopores. With the increase of carbonizate to activator ratio to $1: 4$ (activation temperature $700{ }^{\circ} \mathrm{C}$ ) the volume of adsorbed nitrogen and the number of mesopores in AC structure, increased (Fig. 4, isotherm 1).

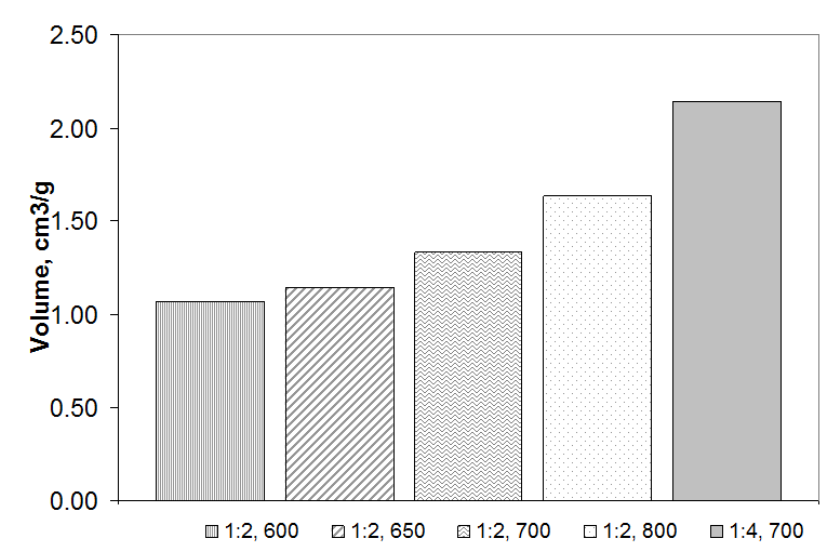

Fig. 5. Micropore volume (left) depending on alteration of activation temperature and carbonizate to activator ratio.

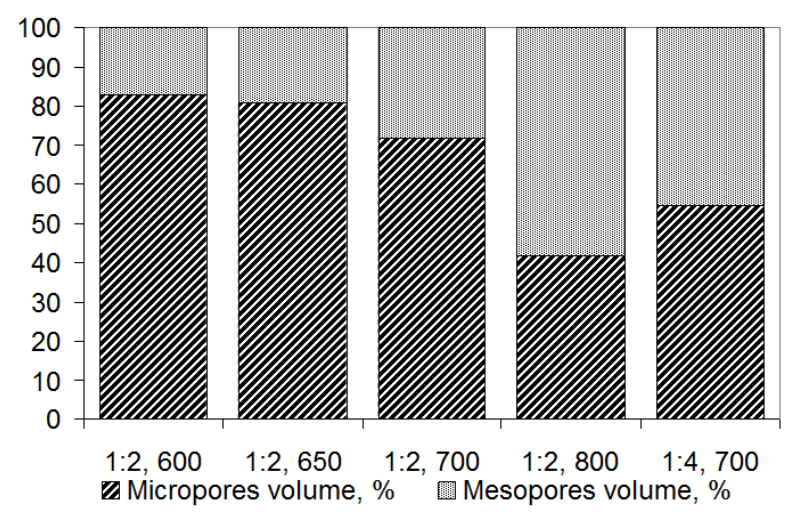

Fig. 6. Micropore to mesopore ratio depending on activation temperature and carbonizate to activator ratio.

Micropore $(0.8 \mathrm{~nm}-1.5 \mathrm{~nm})$ volume increased with the increase of carbonizate to activator ratio and activation temperature in the range $600{ }^{\circ} \mathrm{C}-700{ }^{\circ} \mathrm{C}$ (Fig. 5). Activation at $800{ }^{\circ} \mathrm{C}$ led to decrease of micropore proportion in the structure of AC. This was explained by elimination of pore walls and combining of smaller pores into larger ones. Alongside with the increase of micropore proportion, the total pore volume decreased with the increase of activation temperature and with the increase of carbonizate to activator ratio (Fig. 6). 


\section{Electrochemical Tests}

Characteristics of supercapacitor cells made with electrodes from AC prepared at different activation temperatures and carbonizate to activator ratio $1: 2$ are illustrated in Fig. 7. At low carbonization temperatures $-600{ }^{\circ} \mathrm{C}$ and $700{ }^{\circ} \mathrm{C}-$ the capacitance is $330 \mathrm{~F} \cdot \mathrm{g}^{-1}$ and $320 \mathrm{~F} \cdot \mathrm{g}^{-1}$, correspondingly. Increase of carbonization temperature negatively influences the electrochemical properties - at the activation temperature $800{ }^{\circ} \mathrm{C}$ capacitance decreased to $220 \mathrm{~F} \cdot \mathrm{g}^{-1}$.

As shown in Fig. 7, the total volume of electrolyte retained by electrode considerably increased with the increase of activation temperature. This parameter is important to efficiency of the device under development, namely for the calculation of specific characteristics to the mass of elementary capacitor cell.

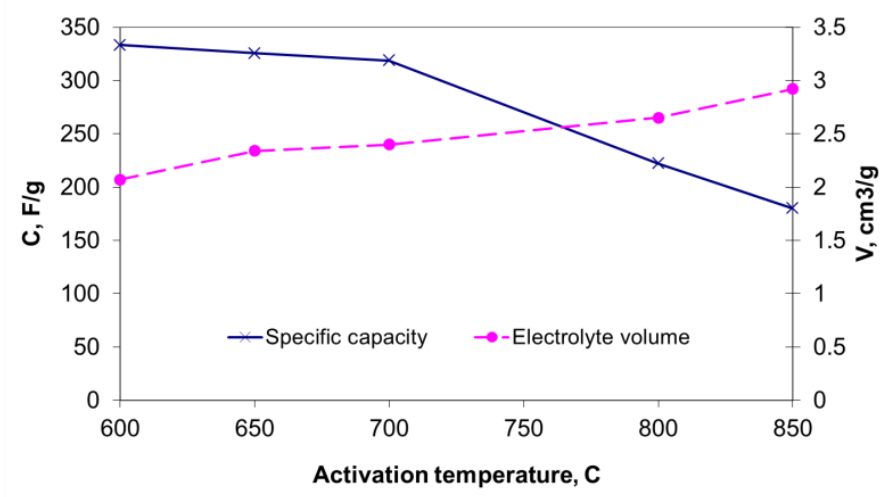

Fig. 7. Dependence of supercapacitor cell capacitance and volume of electrolyte retained by $\mathrm{AC}$ depending on the activation temperature (carbonizate to activator ratio 1:2).

This behavior can be explained by data found in literature [12]. Decreasing the pore size to a value approaching the crystallographic diameter of the ion leads to a $100 \%$ increase of normalized capacitance. It has been shown that under a potential, there is substantial ion motion and diminished dielectric permittivity in pores smaller than the size of the ion solvation shells. The solvation shell becomes highly distorted as the ion is squeezed through the pore, in the same way a balloon distorts when squeezed through an opening smaller than its equilibrium size.

The distortion of solvation shells in small pores of carbon nanostructures was reported recently. Such distortion would allow closer approach of the ion center to the electrode surface that leads to improved capacitance [12].

Thus electrode pores should provide transport and availability of ions in the process of double electric layer charge and discharge. Obviously, there are an optimal micropore volume and size required to effectively form double electric layer. Mesopores and macropores provide transport function for ions of electrolyte. These pores do not contribute to electric double layer formation and additional electrolyte mass negatively influences the SC specific characteristics calculating both for a cell or for a whole device.

To investigate the properties of the obtained nanoporous activated carbons, they were tested in two electrode system.
Charge/discharge cyclic voltammograms were recorded and compared to voltammograms obtained for electrodes based on commercial carbon materials (Fig. 8). All three materials exhibited a regular box-like shape with a steep current change at the switching potential, a characteristic behavior of an ideal capacitor. It is clear that nanoporous activated carbons showed higher specific capacitance. The other benefit of a disperse carbon material is the ability to control thickness of carbon layer.

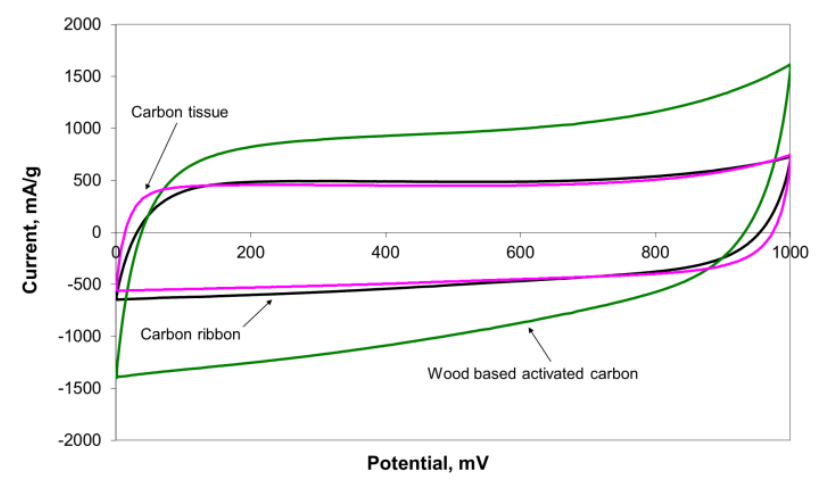

Fig. 8. Cyclic voltammograms (two electrode cells) of capacitors with electrodes built from wood based activated carbons (carbonizate to activator ratio $1: 2$, activation temperature $600^{\circ} \mathrm{C}$ ), commercial carbon tissue electrodes and commercial carbon ribbon electrodes $\left(\mathrm{H}_{2} \mathrm{SO}_{4}\right.$ aqueous solution).

Further research of the carbon porous structure and the synthesis of materials with optimal volume of pores with sizes tailored for specific electrolytes may allow both energy and power characteristics of supercapacitors to be improved.

\section{CONCLUSION}

Microporous wood based carbon materials were obtained using thermocatalytical synthesis, which included carbonization and followed by alkali activation. The synthesized carbon materials had suitable electrode characteristics for capacitors with double electric layer using sulfuric acid as electrolyte. Maximum capacity of supercapacitor $-330 \mathrm{~F} \cdot \mathrm{g}^{-1}-$ is achieved, if the activation temperature is $600{ }^{\circ} \mathrm{C}$ and carbonizate to activator ratio is $1: 2$. Capacity decreased with increase of temperature, which corresponded to decrease of micropore proportion in porous structure of activated carbons .

\section{REFERENCES}

1. Tsyganova, S., Korolkova, I., Bondarenko, G., Chesnokov, N., Kuznetsov, B. Synthesis of Active Carbons from Birch Wood modified by phosphoric Acid and Potassium Hydroxide. J. Siberian Fed University Chemistry, 2009, vol. 2, no. 3, pp. 275-281.

2. Torne-Fernandez, V., Mateo-Sanz, J.M., Montane, D., Fierro, V. Statistical Optimization of the Synthesis of Highly Microporus Carbons by Chemical Activation of Kraft Lignin with $\mathrm{NaOH}$. J. Chem. Eng. Data. 2009, vol. 54, no. 8, pp. 2216-2221. http://dx.doi.org/10.1021/je800827n

3. Marsh, H., Rodriguez-Reinoso, F. Activated Carbon. Amsterdam : Elsevier, 2006, 536 p.

4. Dobele, G., Dizhbite, T., Gil, M.V., Volperts, A., Centeno, T.A. Production of Nanoporous Carbons from Wood Processing Wastes and their use in Supercapacitors and $\mathrm{CO}_{2}$ Capture. Biomass and Bioenergy, 2012, vol. 46, pp. 145-154. http://dx.doi.org/10.1016/j.biombioe.2012.09.010 
5. Bansal, R, Goyal, M. Activated carbons Adsorption, Boca Raton : CRP Press, 2005, 472 p. http://dx.doi.org/10.1201/9781420028812

6. Cheng, Y.H., Tay, B.K., Lau, S.P., Shi, X., Qiao, X.L., Chen J.G., Wu, Y.P., Xie, C.S. Raman spectroscopy of carbon nitride films deposited using the filtered cathodic vacuum-arc combined with a radio-frequency nitrogen-ion beam. Appl. Phys. A. 2001, vol. 73, pp. 341-334. http://dx.doi.org/10.1007/s003390100725

7. Zickler, G.A., Smarsly, B, Gierlinger, N., Peterlik, H., Paris, O. A reconsideration of the relationship between the crystallite size of carbons determined by X-ray diffraction and Raman spectroscopy. Carbon, 2006, vol. 44, pp. 3239-3246. http://dx.doi.org/10.1016/j.carbon.2006.06.029

8. Inagaki, M., Konno, H., Tanaike, O. Carbon Materials for Electrochemical Capacitors. J. Power Sources, 2010, vol. 195, pp. 78807903. http://dx.doi.org/10.1016/j.jpowsour.2010.06.036

9. Rouquerol, J., Rouquerol, F., Sing K. Adsorption by Powders and Porous Solids Principles, Methodology and Applications. San Diego : Academic Press, 1998. $467 \mathrm{p}$

10. Ferrari A. C., Meyer J.C., Scardaci, V.,Casiraghi, C., Lazzeri, S., Mauri, F., Piscanec, S., Jiang, D., Novoselov, A. K., Roth, S., Geim, A. K. Raman Spectrum of Graphene and Graphene Layers. Phys. Rev. $\begin{array}{lll}\text { Lett., } & 2006, & \text { vol. 97, }\end{array}$ http://dx.doi.org/10.1103/PhysRevLett.97.187401

11. Klinke, C., Kurt, R., Bonard, J.M. Raman Spectroscopy and Field Emission Measurements on Catalytically Grown Carbon Nanotubes. $J$. Phys. Chem. B, 2002, vol. 106, pp. 11191-11195. http://dx.doi.org/10.1021/jp0215217

12. Chmiola, J., Yushin, G., Gogotsi, Y., Portet, C., Simon, P., Taberna P.L. Anomalous Increase in Carbon Capacitance at Pore Sizes Less Than 1 Nanometer. Science, 2006, vol. 313, pp. 1760-1763. http://dx.doi.org/10.1126/science.1132195

Aleksandrs Volperts gained a master of science degree at Riga Technical University in 1997 in the field of chemical processes and devices. He gained a master of science degree at Helsinki University of Technology in 1997 in the field of paper production. Since 1998 he has held the position of research assistant at Latvian State Institute of Wood Chemistry.

E-mail: quizzus@marshal.lv
Galina Dobele gained engineer title at Latvian Technical University in 1968 in the field of biologically active substances and $D r$. chem. title at Latvian Sate Institute of Wood Chemistry, in 1984 for work in the field of thermocatalytical conversion of wood and wood components. Galina Dobele gained the Dr. habil. chem. title at Latvian Sate Institute of Wood Chemistry for the research of levoglucosenone formation in the process of thermocatalytical pyrolysis. She held the position of a researcher in 1971 1989 at Latvian Sate Institute of Wood Chemistry, but since 1990 she has held the position of head researcher.

E-mail: gdobele@edi.lv

Jurijs Ozoliňš, Dr. sc. ing., professor, leading researcher at Riga Technical University, Faculty of Materials Science and Applied Chemistry, Institute of General Chemical Engineering. He is an author and a co-author of more than 95 publications in the branch of polymers technology and environmental engineering (mass transfer processes, properties and use of titanium oxide ceramics, microbiological contamination of drinking water). He lectures the following courses: Fluid Flow, Heat and Mass Transfer, Unit Operation of Chemical Engineering, Heat Transfer Processes and Equipment, Special Processes and Equipment, Processes of Materials Technology.

E-mail: juris_oz@inbox.lv

Nina Mironova-Ulmane gained master of science degree in the field of nuclear physics at the University of Latvia in 1964 and Dr. phys. degree at the University of Latvia in 1976. She gained the doctoral title in physics and math ( Higher Attestation Commission, USSR) in 1989 and title Dr. habil. phys. at the University of Latvia in 1991. Between 1967 and 1992 she was an aspirant, a junior researcher and a senior researcher at Latvian Academy of Sciences, Institute of Physics. Between 1992 and 1994 Nina Mironova-Ulmane was the head of Oxide Physics Laboratory at Latvian Academy of Sciences, Institute of Physics. Between 1994 and 1999 Professor of Latvian Nuclear Research Centre. Between 1996 and 2003 she was a professor at Riga Technical University. And since 2000 she is a senior researcher at the University of Latvia, Institute of Solid State Physics.

E-mail: nina@cfi.lu.lv

\begin{abstract}
Aleksandrs Volperts, Galina Dobele, Jurijs Ozoliṇš, N̦ina Mironova-Ulmane. Nanoporaino aktivēto ogḷu sintēze un pielietošana superkondensatoros.

Izpētīta termokatalītiskās sintēzes apstākḷu ietekme uz mikroporainu oglekḷa materiālu uz koksnes bāzes veidošanos un īpašībām. Iegūtās mikroporainas aktivētās ogles raksturotas izmantojot slāpekḷa sorbciju un Ramana spektrometriju. Pētîts iegūto ogļu pielietojums elektrodos kondensatorā ar dubulto elektrisko slāni (superkondensatorā). Aktivācijas temperatūras un sārmainā aktivatora daudzuma izmaiņas var izmantot ne tikai, lai kontrolētu kopīgo poru tilpumu, bet arī, lai regulētu mikroporu un mezoporu proporcijas. Pētīts iegūto ogḷu pielietojums superkondensatoru elektrodos, kā arī oglekḷa materiālu porainās struktūras ietekme uz elektrodu darbību, izmantojot ciklisko voltamperometriju. Parādīts, ka aktivācijas temperatūras palielināšana no $600^{\circ} \mathrm{C}$ līdz $800^{\circ} \mathrm{C}$ izraisa mezoporu tilpuma daḷas palielināšanos porainajā struktūrā un tas negatīvi ietekmē superkondensatora šūniņas ietilpību. Aktivēto ogḷu, kas paredzētas pielietošanai superkondensatoros ar elektrolītu uz sērskābes bāzes, sintēzei visizdevīgākā ir aktivācija zemu temperatūrā. Salīdzināti superkondensatori uz iegūto mikroporaino aktivēto ogḷu bāzes ar superkondensatoriem uz komerciālo ogḷu paraugu bāzes, kā arī izskaidrota palielinātā ietilpība šaurās nanoroporās. Apspriests arī turpmāko pētījumu virziens.
\end{abstract}

Александрс Волпертс, Галина Добеле, Юрий Озолиньш, Нина Миронова-Улмане. Синтез нанопористого активированного угля и его применение в суперконденсаторах.

Исследовано влияние условий термокаталитического синтеза на формирование и свойства микропористых углеродных материалов на основе древесины. Полученный микропористый активированный углоль различных видов был охарактеризован методами сорбции азота и Рамановской спектрометрии. Приведены результаты использования полученного активированного угля в качестве электродов в конденсаторах с двойным электрическим слоем - суперконденсаторах. Было установлено, что изменение температуры активации и дозировки щелочного активатора может быть использовано не только для контроля за общим объемом пор, но и для регулирования пропорции микро- и мезопор. При помощи циклической вольтамперометрии показаны результаты исследования полученных видов угля в качестве электродов суперконденасаторов и влияние свойств пористой структуры углеродных материалов на рабочие характеристики электродов. Продемонстрировано, что увеличение температуры активации с $600{ }^{\circ} \mathrm{C}$ до $800{ }^{\circ} \mathrm{C}$ ведет к увеличению доли мезопор в пористой структуре, что негативно влияет на емкость ячейки суперконденсатора. Было установлено, что для синтеза углей для применения в супеконденсторах с электролитом на основе серной кислоты наиболее выгодным является низкотемпературный режим активации. Проведено сравнение суперконденсаторов на основе полученных микропористого активированного угля с суперконденасторами на основе коммерческих углеродных материалов и объяснен феномен повышенной электрической емкости в узких нанопорах, а также дальнейшее направление исследований. 